\title{
Variation in annual pollen accumulation rates of Fagus along a N-S transect in Europe based on pollen traps
}

\author{
Irena A. Pidek • Helena Svitavská-Svobodová • Willem O. van der Knaap • \\ Agnieszka M. Noryśkiewicz • Anna Filbrandt-Czaja • Bożena Noryśkiewicz • \\ Małgorzata Latałowa $\cdot$ Marcelina Zimny • Joanna Święta-Musznicka • \\ Elissaveta Bozilova $\cdot$ Spassimir Tonkov $\cdot$ Mariana Filipova-Marinova \\ Anneli Poska • Thomas Giesecke • Aleksander Gikov
}

Received: 8 December 2009/ Accepted: 1 March 2010

(C) Springer-Verlag 2010

\begin{abstract}
Annual pollen-accumulation rates (PAR) of Fagus (beech) obtained within the framework of the Pollen Monitoring Programme (PMP) were analyzed in pollen traps along a N-S transect from the Baltic Sea to the Black Sea in different European vegetation units. The study regions are situated in the lowlands of northern Poland, the uplands of SE Poland, the Czech Krkonoše Mts, the Czech Šumava Mts, the Swiss Jura Mts, the Swiss Alps, the
\end{abstract}

Communicated by F. Bittmann.

Electronic supplementary material The online version of this article (doi:10.1007/s00334-010-0248-0) contains supplementary material, which is available to authorized users.

I. A. Pidek $(\bowtie)$

Institute of Earth Sciences, Maria Curie-Skłodowska University Lublin, al Kraśnicka 2 c/d, 20-718 Lublin, Poland

e-mail: i.pidek@poczta.umcs.lublin.pl

H. Svitavská-Svobodová

Institute of Botany, Academy of Sciences of Czech Republic, Castle, 25243 Průhonice, Czech Republic

e-mail: svitavska@ibot.cas.cz

W. O. van der Knaap

Institute of Plant Sciences and Oeschger Centre for Climate Change Research, University of Bern, Altenbergrain 21,

3013 Bern, Switzerland

e-mail: Pim.vanderKnaap@ips.unibe.ch

\section{A. M. Noryśkiewicz}

Institute of Archaeology, Nicolaus Copernicus University Torun, Szosa Bydgoska 44/48, 87-100 Toruń, Poland

e-mail: anorys@umk.pl

\section{A. Filbrandt-Czaja}

Institute of Ecology and Nature Protection, Nicolaus Copernicus University Torun, Gagarina 9, 87-100 Torun, Poland

e-mail: afczaja@umk.pl
Bulgarian Rila Mts and the Bulgarian Strandzha Mts. Most time series are 10 or 11 years long, some are 5-16 years long. Inter-annual fluctuations in Fagus PAR were analyzed and compared with seed mast years. Years with high Fagus PAR and others with low Fagus PAR occurred most frequently in parallel within each region and often in two neighbouring regions. 2006 was exceptional as it had a very high Fagus sylvatica pollen deposition in all study regions and it was also a mast year. In Bulgaria, the trend in the 5 years of Fagus orientalis PAR in the Strandzha Mts differed from that of $F$. sylvatica PAR in the Rila Mts. Aiming at establishing the relationship between average Fagus PAR and tree cover, differences in Fagus PAR

\section{B. Noryśkiewicz}

Institute of Geography, Nicolaus Copernicus University Torun, Gagarina 9, 87-100 Torun, Poland e-mail: norys@umk.pl

M. Latałowa · M. Zimny · J. Święta-Musznicka

Laboratory of Palaeoecology and Archaeobotany, Department of Plant Ecology, University of Gdańsk, al. Legionów 9, 80-441 Gdańsk, Poland

e-mail: bioml@univ.gda.pl

M. Zimny

e-mail: marcelina.zimny@univ.gda.pl

J. Święta-Musznicka

e-mail: lasaint@wp.pl

E. Bozilova $\cdot$ S. Tonkov

Department of Botany, Faculty of Biology, Sofia University of St. Kliment Ohridski, 8 Dragan Tzankov blvd, 1164 Sofia, Bulgaria

e-mail: bozilova@biofac.uni-sofia.bg

S. Tonkov

e-mail: tonkov@biofac.uni-sofia.bg 
(averaged per pollen trap) were related in each region to the proportion of beech trees in the vegetation within $2 \mathrm{~km}$ of the pollen traps, the distance to the nearest pollinating Fagus tree, regional or local presence of beech forests, the degree of landscape openness, and the size of forest opening in which a trap is situated. Average Fagus PAR was found to track the regional abundance of beech trees in the vegetation, not the distance of the nearest Fagus tree. Regional occurrence of beech-dominated forests was reflected by a Fagus PAR of ca. 1,400 grains $\mathrm{cm}^{-2}$ year $^{-1}$, local abundance very close to pollen traps by ca. 2,400 grains, small patches of forest with admixture of Fagus by ca. 170-220 grains, and scarcity or absence of Fagus by ca. 40 grains or less.

Keywords Fagus - Europe - Tree cover ·

Pollen monitoring - Tauber traps .

Pollen accumulation rates · Pollen-vegetation relationship

\section{Introduction}

In recent years much effort has been put into the clarification of the relationships between the abundance of a taxon in the vegetation and its representation in pollen spectra, using different approaches (Sugita 1994; Calcote 1995; Hjelle 1998; Broström et al. 2004, 2008; Gaillard et al. 2008; Sjögren et al. 2008). In addition to general information concerning the relation between pollen loading and vegetation, modern pollen assemblages derived from yearly deposition in Tauber-type pollen traps (Hicks and Hyvärinen 1986; van der Knaap et al. 2001) offer interesting insights into different aspects of the processes responsible for the formation of the pollen spectra. The use of annual pollen traps enables us to calculate annual pollen deposition of individual taxa with confidence (pollen

M. Filipova-Marinova

Museum of Natural History, 41 Maria Louisa blvd, 9000 Varna, Bulgaria

e-mail: marianafilipova@yahoo.com

\section{A. Poska}

Institute of Ecology and Earth Sciences, University of Tartu,

Vanemüise 46, 51014 Tartu, Estonia

e-mail: anneli.poska@ut.ee

\section{T. Giesecke}

Albert-von-Haller-Institute for Plant Sciences, University of Göttingen, Untere Karspüle 2, 37073 Göttingen, Germany e-mail: Thomas.Giesecke@biologie.uni-goettingen.de

\section{A. Gikov}

Space Research Institute, Bulgarian Academy of Sciences, 6 Moskovska Str., 1000 Sofia, Bulgaria

e-mail: gikov@mail.space.bas.bg accumulation rates or PAR; also referred to as pollen influx) and, in a next step, to relate the inter-annual variation in pollen deposition to seasonal meteorological changes (Hicks 1996; Huusko and Hicks 2009; van der Knaap et al., this volume). This type of results can be used for the interpretation of fossil pollen data expressed as proportions or as PAR (Hicks et al. 1996). The main advantage of pollen traps over surface samples is that the former provide an independent pollen record for each taxon, unaffected by changes in abundance of other taxa (Hicks 2005; Seppä and Hicks 2006).

In the last decade, the post-glacial history of most major tree taxa in Europe was thoroughly investigated (e.g. Brewer et al. 2002; Terhürne-Berson et al. 2004; Cheddadi et al. 2006; Magri et al. 2006; Latałowa and van der Knaap 2006; Tollefsrud et al. 2008; Liepelt et al. 2009). These studies are of basic relevance for a better understanding of the long-term ecological processes driving the spread, establishment and persistence of individual tree populations. In addition to their scientific interest, the results are indispensable for modern forest management based on scientifically built scenarios of future environmental change (Birks 1996; Botkin et al. 2007). Beech (Fagus) for example, as one of the main forest-forming trees in Europe, is subject to increasing interest.

Among the two European beech species, Fagus sylvatica L. is widely distributed, whereas Fagus orientalis Lipsky grows only in a restricted area of south-eastern Europe, e.g. Bulgaria, Greece, Romania, and Turkey (Jalas and Suominen 1972-1999). The range of $F$. sylvatica covers southern, central and western Europe, reaching the southern British Islands and southern Scandinavia. As a sub-Atlantic species, avoiding areas of continental climate, it reaches its eastern distribution limit in eastern Poland (Fig. 1). Within its main area of distribution it is absent from the Great Hungarian Plain with its more continental climate and also from the lower Danube and Po valleys.

Several aspects of the post-glacial history of $F$. sylvatica have been thoroughly studied on different spatial scales. In the last few years several papers have appeared with new data concerning the formation of its modern European distribution (Magri et al. 2006; Tinner and Lotter 2006; Giesecke et al. 2007; Bradshaw 2008).

This study aims at a better understanding of the representation of Fagus in pollen spectra, with a focus on the inter-annual variability of Fagus pollen deposition. Our analyses are based on the results from a large number of sites established within the framework of the Pollen Monitoring Programme-PMP (Hicks et al. 1996). The sites are located along a N-S transect across different European vegetation units within the distribution range of Fagus from the Baltic Sea coast in Poland to the Black Sea coast in Bulgaria. This enables us to study the different 
Fig. 1 Study areas in Europe with the distribution range of $F$. sylvatica (after Latałowa et al. 2004, and references therein; EUFORGEN 2009)

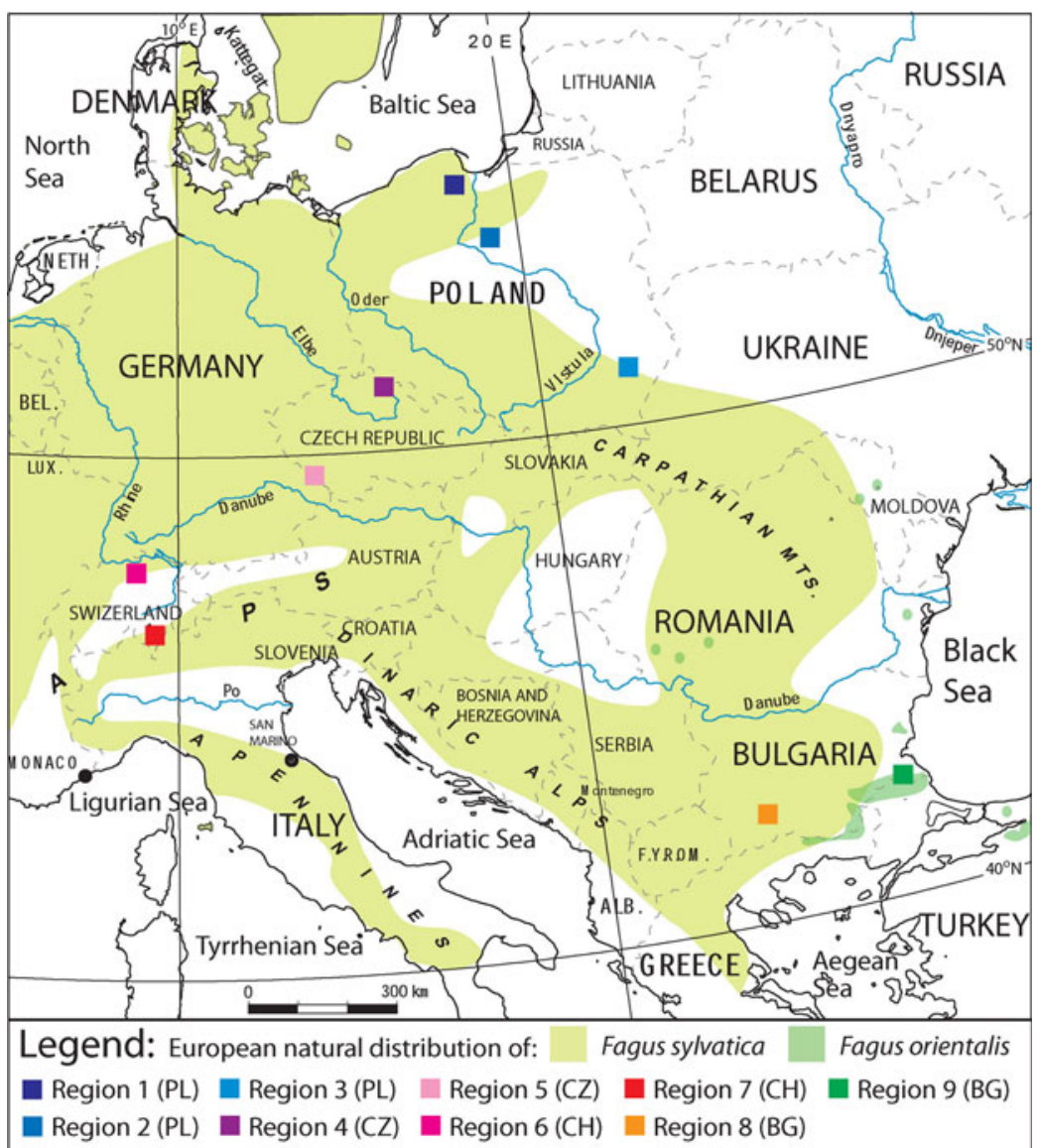

patterns of high and low pollen-production years in regions differing in climate and vegetation. Variation in Fagus pollen deposition is compared to the general abundance of the tree, in order to evaluate to what extent the presence and abundance of Fagus can be described by the abundance of its pollen in sediments.

Study areas

In the present study we used the results from 106 pollen traps from the PMP network. These selected traps encompass nine regional datasets that are situated within the distribution of $F$. sylvatica and $F$. orientalis (Fig. 1). Detailed regional descriptions and particulars of the individual setup of pollen traps are summarized in Giesecke et al. (this volume). Regions 1-9 have been sub-divided into sub-regions based on vegetation features. The relevant regions and sub-regions for this study are (see Appendix 1, ESM):

- Region 1-Northern Poland (sub-regions: Gdańsk region, Kashubian Lakeland, Tuchola Forests).

- Region 2-North-central Poland (sub-regions: Brodnica Lakeland, Toruń Basin).
- Region 3-South-eastern Poland (Roztocze region).

- Region 4-The Krkonoše Mts in the Czech Republic.

- Region 5-The Šumava Mts in the Czech Republic.

- Region 6-The Jura Mts in Switzerland.

- Region 7-The Alps in Switzerland.

- Region 8-The Rila Mts in Bulgaria.

- Region 9-The Strandzha Mts in Bulgaria.

\section{Materials and methods}

Pollen deposition was monitored by standardized pollen traps of Tauber's (1974) general design with modifications described by Hicks and Hyvärinen (1986) and Hicks et al. (1996). A $5 \mathrm{~cm}$ diameter opening was used in most traps, although in the Kashubian Lakeland, Bulgaria, and several Czech sites the opening varied from 3.5 to $7 \mathrm{~cm}$. At most sites the pollen data series cover the period of 10 or 11 years, 1998-2007 or 1998-2008. In most of the Swiss Alps 16 years are represented (19922007). The series is shorter in the Jura Mts (2002-2007), the Gdańsk region and the Kashubian Lakeland (20042008), and the Strandzha Mts (2002-2006). The trap 
bottom was covered by a mixture of glycerine, thymol and formaline in the recommended proportions (Hicks et al. 1996). The traps remained in the field all year round (October-October) with the opening just above the ground surface. The trap contents were subjected to laboratory treatment followed by microscopic analysis. Lycopodium tablets (Stockmarr 1971) were added at an early stage of laboratory treatment, followed by sieving through a coarse sieve, concentration and Erdtman's acetolysis by standard methods used in pollen analysis. The following details of laboratory treatment differed among regions. The trap contents were concentrated by filtering, centrifuging, or siphoning after cold storage for a minimum of 5 weeks, or a combination of these methods. Five Lycopodium tablets were added to each trap in most cases, one or two in the Swiss Alps in 1992-1994, three in Bulgaria, and in Poland up to ten in the Brodnica Lakeland and the Wierzchlas Reserve and seven in the Gdańsk region and Kashubian Lakeland. More detail is provided in Tonkov et al. (2001), van der Knaap et al. (2001) and Pidek (2004).

Average Fagus PAR was calculated for each trap individually and for each region as a whole.

For various reasons (damage or theft of a trap etc.), the available dataset was in some cases smaller that the number of years included. Several clear outliers were observed in some years in a number of traps, but they were not removed from the averages, as the occasional occurrence of two outliers in the same trap suggests that they are related to weather conditions (see van der Knaap et al., this volume).

Information on low and high seed production (mast) relevant for the regions was collected whenever possible. The sources are Załęski et al. (1999-2008), Hilton and Packham (2003) and Z. Procházková, D. Černý, A. Burkart, K. Galabov, B. Taseva and G. Popov (pers. commun., 2009).

The vegetation was described in a radius of up to $2 \mathrm{~km}$ around each selected pollen trap, which represents the area from which most Fagus pollen would originate (Sugita 1994; Poska and Pidek 2010). Aerial photographs, relevant literature and field observations were used to estimate the size of the forest opening, the degree of landscape openness, the proportion of beech trees in the forest and the distance to the nearest pollinating Fagus tree. A brief description of site types (open landscape, forest opening/edge) and the distance of the nearest Fagus tree are given in Appendix 1 (ESM). These descriptions are not always fully quantitative, so that results based on this data show robust trends although the actual values may be biased.

\section{Results}

Inter-annual variation in Fagus PAR values

The pollen traps from most regions show large variability in the annual deposition of Fagus pollen and the variability between years in the same trap was generally larger than between traps for the same year. We classified the annual values based on each pollen trap, in order to compare the temporal pattern between traps. Four classes of Fagus PAR values were distinguished: low ( $<70 \%$ of average), average, high ( $>130 \%$ of average), extremely high $(>2 \times$ the average). Average values are presented in Appendix 2 (ESM). Regional summaries of these classifications are presented in Table 1 and compared to reported information on seed production in the different years for selected regions.

According to Załęski et al. (1999-2008), seed production in a forest stand was estimated in the following categories: (a) low production-seeds are produced only by trees growing at the edges of the forest stand (ca. 10\% of trees); (b) average production-numerous trees produce seeds, not only at the edge but also a small number inside the forest (ca. 30\% of trees); (c) good mast-a significant proportion of trees produces seeds (close to $100 \%$ of trees).

Annual PAR values were averaged for pollen traps from the same forest or sub-region and these summarized time series from different localities are plotted beside each other for comparison in Fig. 2. This summary shows that in many regions most Fagus trees in the same forest have parallel high and low flowering years, which gives rise to the often high variability in inter-annual pollen deposition on the regional scale. However, the pollen traps in particular from the Strandzha Mountains beside the Black Sea coast in Bulgaria show a different pattern. Here the three pollen traps indicate that the year-to-year variability in pollen production may not be parallel between the individual trees. Also, the values are always high compared to the other regions due to the close proximity of Fagus forest, and the little variation between years is almost cancelled out. No clear pattern is visible as the time series is rather short. In 2004, for example, the high PAR in trap BG BS8 (4,084 grains cm ${ }^{-2}$ year $\left.^{-1}\right)$ coincides with the lowest PAR of trap BG BS9 (1,924 grains $\mathrm{cm}^{-2}$ year $\left.^{-1}\right)$. In 2005, on the other hand, the two traps showed an opposite pattern, and also a third trap had a very high PAR. We do not expect any trends in common between $F$. orientalis PAR in this region and $F$. sylvatica PAR in the other region in Bulgaria due to the large distance and difference in climate between the two regions.

The next most striking feature of the dataset is the coincidence of the low flowering year 2005, which is 
Table 1 Trends of Fagus pollen deposition along a N-S transect in Europe (1998-2007) in relation to estimated seed production

\begin{tabular}{|c|c|c|c|c|c|c|c|c|c|c|}
\hline Region & 1998 & 1999 & 2000 & 2001 & 2002 & 2003 & 2004 & 2005 & 2006 & 2007 \\
\hline $\begin{array}{l}\text { N Poland } \\
\text { Pollen deposition }\end{array}$ & low $86 \%$ & low $92 \%$ & \begin{tabular}{|l|} 
very high $17 \%$ \\
high $25 \%$ \\
average $25 \%$ \\
\end{tabular} & low $87 \%$ & $\begin{array}{l}\text { average } 15 \% \\
\text { low } 65 \%\end{array}$ & $\begin{array}{l}\text { average } 21 \% \\
\text { low } 57 \%\end{array}$ & $\begin{array}{l}\text { very high } 39 \% \\
\text { high } 22 \%\end{array}$ & low $100 \%$ & $\begin{array}{l}\text { very high } 83 \% \\
\text { high } 1 \%\end{array}$ & low $73 \%$ \\
\hline Seed production ${ }^{1}$ & high & very low & very good mast & very low & low & average & high & very low & very good mast & low \\
\hline $\begin{array}{l}\text { SE Poland } \\
\text { Pollen deposition } \\
\text { Seed production }\end{array}$ & low $67 \%$ & low $89 \%$ & $\begin{array}{l}\text { very high } 14 \% \\
\text { high } 29 \% \\
\text { average } 43 \% \\
\text { very good mast }\end{array}$ & low $100 \%$ & $\begin{array}{l}\text { high } 38 \% \\
\text { average } 63 \% \\
\text { average }\end{array}$ & $\begin{array}{l}\text { very high 63\% } \\
\text { high } 38 \% \\
\text { average }\end{array}$ & low $67 \%$ & low $71 \%$ & $\begin{array}{l}\text { very high } 88 \% \\
\text { high } 13 \% \\
\text { very good mast }\end{array}$ & $\begin{array}{l}\text { average } 33 \% \\
\text { low } 56 \% \\
\text { low }\end{array}$ \\
\hline $\begin{array}{l}\text { Krkonoše Mts } \\
\text { (Czech Republic) } \\
\text { Pollen deposition }\end{array}$ & $\begin{array}{l}\text { average } 53 \% \\
\text { low } 47 \%\end{array}$ & $\begin{array}{l}\text { average } 35 \% \\
\text { low } 35 \%\end{array}$ & low $73 \%$ & $\begin{array}{l}\text { very high } 39 \% \\
\text { high } 17 \% \\
\text { average } 28 \%\end{array}$ & low $79 \%$ & $\begin{array}{l}\text { very high } 39 \% \\
\text { high } 5 \% \\
\text { average } 39 \%\end{array}$ & low $80 \%$ & low $82 \%$ & $\begin{array}{l}\text { very high } 21 \% \\
\text { high } 7 \% \\
\text { average } 50 \%\end{array}$ & $\begin{array}{l}\text { very high } 40 \% \\
\text { high } 33 \%\end{array}$ \\
\hline $\begin{array}{l}\text { Sumava Mts } \\
\text { (Czech Republic) } \\
\text { Pollen deposition }\end{array}$ & $\begin{array}{l}\text { average } 36 \% \\
\text { low } 50 \%\end{array}$ & $\begin{array}{l}\text { low } 59 \% \\
\text { average } 18 \%\end{array}$ & $\begin{array}{l}\text { low } 60 \% \\
\text { average } 40 \%\end{array}$ & $\begin{array}{l}\text { very high } 39 \% \\
\text { high } 22 \% \\
\text { average } 33 \%\end{array}$ & low $88 \%$ & $\begin{array}{l}\text { average } 29 \% \\
\text { low } 36 \%\end{array}$ & low $82 \%$ & low $94 \%$ & $\begin{array}{l}\text { very high } 38 \% \\
\text { high } 19 \% \\
\text { average } 31 \%\end{array}$ & $\begin{array}{l}\text { very high 19\% } \\
\text { high } 13 \% \\
\text { average } 44 \%\end{array}$ \\
\hline $\begin{array}{l}\text { Seed production } \\
\text { Czech Republic }^{1}\end{array}$ & average & average & high & very good mast & low & high & low & low & very good mast & good mast \\
\hline $\begin{array}{l}\text { Swiss Alps and } \\
\text { Swiss Jura Mts } \\
\text { Pollen deposition }\end{array}$ & low $94 \%$ & $\begin{array}{l}\text { high } 25 \% \\
\text { average } 45 \%\end{array}$ & low $100 \%$ & $\begin{array}{l}\text { average } 22 \% \\
\text { low } 56 \%\end{array}$ & $\begin{array}{l}\text { average } 30 \% \\
\text { low } 70 \%\end{array}$ & $\begin{array}{l}\text { average } 44 \% \\
\text { low } 40 \%\end{array}$ & $\begin{array}{l}\text { very high } 63 \% \\
\text { high } 15 \%\end{array}$ & low $100 \%$ & $\begin{array}{l}\text { very high } 46 \% \\
\text { high } 27 \%\end{array}$ & $\begin{array}{l}\text { average } 40 \% \\
\text { low } 44 \%\end{array}$ \\
\hline Seed production' ${ }^{\prime}$ & low & very good mast & low & rather good mast & low & rather good mast & average & low & rather good mast & low \\
\hline $\begin{array}{l}\text { Rila Mts } \\
\text { (Bulgaria) } \\
\text { Pollen deposition }\end{array}$ & $\begin{array}{l}\text { very high } \\
50 \%(1) \\
\text { low } 50 \%(1)\end{array}$ & very high $100 \%$ (1) & low $100 \%(2)$ & $\begin{array}{l}\text { very high } 50 \%(1) \\
\text { low } 50 \%(1)\end{array}$ & low 100\% (1) & low $100 \%(2)$ & average $100 \%(1)$ & $\begin{array}{l}\text { high } 50 \%(1) \\
\text { average } 50 \%(1)\end{array}$ & low $100 \%$ (1) & $\begin{array}{l}\text { high } 50 \%(1) \\
\text { average } 50 \%(1)\end{array}$ \\
\hline Seed production ${ }^{1}$ & low & very good mast & low & low & low & low & average & very good mast & average & very good mast \\
\hline $\begin{array}{l}\text { Strandzha Mts } \\
\text { (Bulgaria) } \\
\text { Pollen deposition } \\
\text { Seed production } \\
\end{array}$ & & & & & \begin{tabular}{|l} 
average $50 \%(1)$ \\
low $50 \%(1)$ \\
average
\end{tabular} & $\begin{array}{l}\text { high } 66 \% \text { (2) } \\
\text { low } 33 \% \\
\text { average }\end{array}$ & $\begin{array}{l}\text { very high } 50 \% \text { (1) } \\
\text { low } 50 \%(1) \\
\text { average }\end{array}$ & $\begin{array}{l}\text { very high } 33 \% \text { (1) } \\
\text { average } 33 \%(1) \\
\text { low } 33 \%(1) \\
\text { average }\end{array}$ & $\begin{array}{l}\text { high } 33 \% \text { (1) } \\
\text { low 66\% (2) } \\
\text { average }\end{array}$ & very good mast \\
\hline
\end{tabular}

Deposition classes are described in the text; low values are in red, average and high in black, and very high in green; in brackets are numbers of traps. Percentages are proportion of traps of the class in that particular year

1 Seed production data in Poland was based on Załęski et al. (1999-2008), in the Czech Republic on Zdenka Prochazkova and Daniel Cerny (pers. commun., 2009), in Bulgaria (Strandzha) on G. Popov (pers. commun., 2009), in Bulgaria (Rila) on K. Galabanov and B. Taseva (pers. commun., 2009), in Switzerland on A. Burkart (pers. commun., 2009)

clearly visible in all regions except Bulgaria. This year is often framed by 1 or 2 years with extremely high pollen deposition. Especially the year 2006 stands out as a high flowering year in many regions. In several examples clear synchronicities can be seen between sub-regions of the same country such as between the different mountain regions of the Swiss Alps or of the Czech Republic. Still all pollen traps in one region only seldom show completely synchronous variability in pollen deposition, and if they do then only for low flowering years. Only in Poland did as much as $80 \%$ or more of the pollen traps show the year 2006 as an extremely high flowering year. Five out of eight pollen traps in the Roztocze region in south-eastern Poland also show extremely high pollen deposition for the year 2003, while only two out of 14 traps show extreme values in northern Poland for the same year.

It is interesting to note that the estimates of annual Fagus seed production follow the variability of annual pollen deposition rather well. However, there are also marked mismatches. In northern Poland seed production in 1998 was reported as high and in south-eastern Poland as average, while the pollen traps documented a low flowering year in both regions. In Switzerland, seed production in the year
2003 was reported as above average and in 2004 as below average, whereas the pollen traps documented abundant flowering in 2004, but not in 2003. The low pollen-production year 2005, as well as extremely high values for 2006 , is paralleled by reports on seed production or masting.

Comparison of Fagus PAR with the abundance of Fagus trees

Our data show clearly that the average deposition of Fagus pollen in each site (Fig. 3) can be explained by the regional abundance of the tree modulated by local site-specific factors (Table 2; Fig. 4). This is visible in Fig. 4c and d, which show that the proportion of Fagus in the regional vegetation is only explaining about $40 \%$ of the variance in pollen deposition in the individual traps, but about $85 \%$ of the variance in sub-regional averages of PAR.

When comparing the deposition of Fagus pollen against the distance of the nearest tree, we find that the highest PARs were obtained under the canopy or in small openings. This is exemplified in a pair of traps within beech forests from Roztocze (Poland), where an under-canopy trap (PL G9) has collected more than twice the amount of 


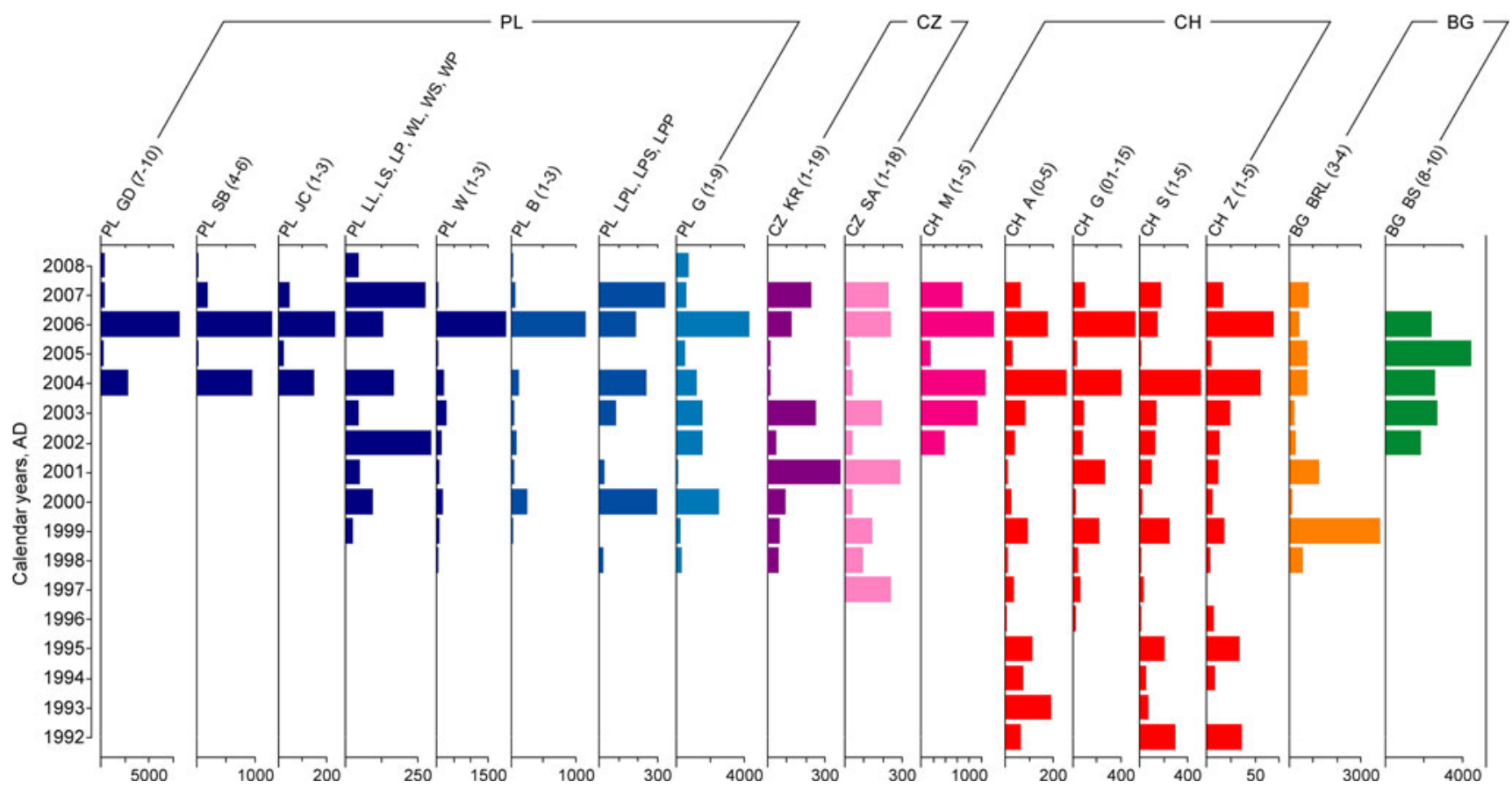

Fig. 2 Average annual Fagus PAR values from the same forest or sub-region; for colour code, see Fig. 1

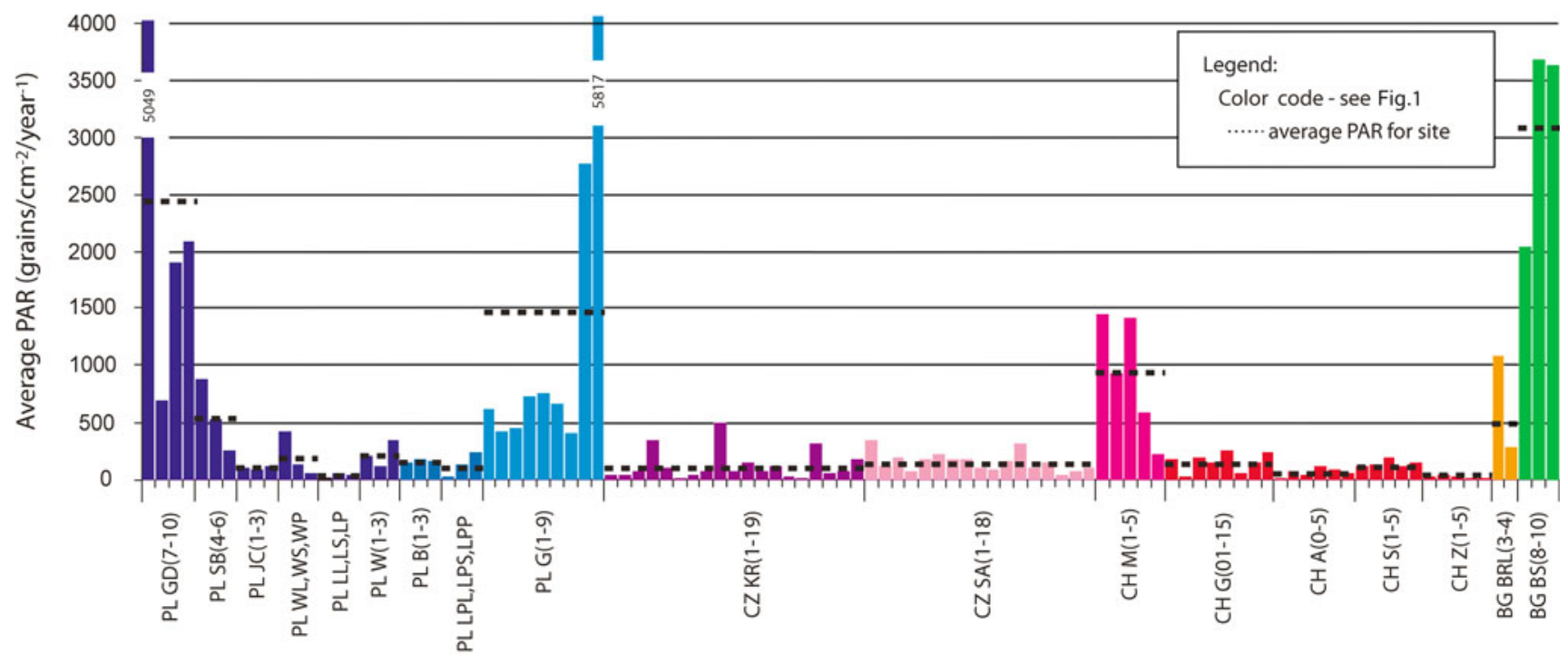

Pollen trapping sites

Fig. 3 Average deposition of Fagus pollen in each pollen trapping site; for colour code, see Fig. 1

pollen than a nearby trap in a large opening (PL G8). The influence of the distance of the pollen trap to the nearest flowering tree is also visible in a situation with low regional Fagus abundance-Las Piwnicki Reserve in Toruń Basin (Poland) contains a single Fagus tree and the average pollen deposition $200 \mathrm{~m}$ away from the tree in a trap under the canopy amounts to 137 grains $\mathrm{cm}^{-2}$ year $^{-1}$, while ca. $500 \mathrm{~m}$ away in the open an average of 34 grains $\mathrm{cm}^{-2}$ year $^{-1}$ was estimated.
In Table 2 we summarized the sub-regional averages according to general classes of regional Fagus abundance. Here it is interesting to note that the average PAR from a $F$. sylvatica dominated forest in northern Poland is similar to values from a $F$. orientalis forest near the Black Sea coast, although the northern Polish traps show high interannual variability whereas the traps from the Black Sea coast show little variability. The lower values for the Rila Mountains are easily explained by the position of the pollen 
Table 2 Average regional PAR against the background of vegetation

\begin{tabular}{l|l|l|l|l}
\hline Region & Names and symbols of pollen traps & $\begin{array}{l}\text { Distance to } \\
\text { nearest } \\
\text { Fagus trees }\end{array}$ & $\begin{array}{l}\text { Fagus PAR } \\
\text { (grains } \\
\text { cm }^{-2} \text { year }^{-1} \text { ) }\end{array}$ & $\begin{array}{l}\text { Years of pollen } \\
\text { data series }\end{array}$ \\
\hline
\end{tabular}

Vast areas of Fagus dominated forest communities up to $2 \mathbf{k m}$ around pollen traps

\begin{tabular}{l|l|l|l|l}
\hline N Poland & $\begin{array}{l}\text { Gdańsk region (Gołębiewo site; F. sylvatica } \\
\text { dominated forest within the range of } \\
\text { Pomeranian beech forests) } \\
\text { Traps: Gd7, Gd8, Gd9, Gd10 }\end{array}$ & $2-50 \mathrm{~m}$ & 2,433 & $\begin{array}{l}5 \text { years } \\
2004-2008\end{array}$ \\
\hline SE Poland & $\begin{array}{l}\text { Roztocze region (Guciow site; F. sylvatica } \\
\text { dominated forest within the range of } \\
\text { Carpathian beech forests) } \\
\text { Traps: G1, G2, G3, G4, G5, G6, G7, G8, G9 }\end{array}$ & $5-500 \mathrm{~m}$ & 1,407 & $\begin{array}{l}11 \text { years } \\
1998-2008\end{array}$ \\
\hline SW Bulgaria & $\begin{array}{l}\text { Rila Mts }(F . \text { sylvatica forest belt at the } \\
\text { elevation of 1,000-1,600 m asl) } \\
\text { Traps: BRL3, BRL4 }\end{array}$ & $\begin{array}{l}470-1,000 \mathrm{~m} \\
\text { downslope }\end{array}$ & 688 & 10 years \\
\hline Swiss Jura Mts & $\begin{array}{l}\text { Jura Mts (Marcheiruz site) } \\
\text { Traps: M1, M2, M3, M4, M5 }\end{array}$ & $\begin{array}{l}\text { Strandzha Mts }(F . \text { orientalis dominated forest } \\
\text { close to the traps) } \\
\text { Traps: BS8, BS9, BS10 }\end{array}$ & $3-5 \mathrm{~m}$ & 2,4607 \\
\hline $\begin{array}{l}\text { S Bulgarian } \\
\text { Black Sea coast }\end{array}$ & $\begin{array}{l}6 \text { years } \\
2002-2007\end{array}$ & $\begin{array}{l}5 \text { years } \\
2002-2006\end{array}$ \\
\hline
\end{tabular}

Small patches of Fagus dominated forest within $2 \mathrm{~km}$ from pollen traps

\begin{tabular}{l|l|l|l|l}
\hline \multirow{2}{*}{ N Poland } & $\begin{array}{l}\text { Kashubian Lakeland ( Staniszewskie Bog site) } \\
\text { Traps: SB4, SB5, SB6 }\end{array}$ & $20-30 \mathrm{~m}$ & 558 & $\begin{array}{l}5 \text { years } \\
2004-2008\end{array}$ \\
\cline { 2 - 5 } & $\begin{array}{l}\text { Tuchola Forests (Widno sites) } \\
\text { Traps: WL, WS, WP }\end{array}$ & $20-400 \mathrm{~m}$ & 211 & $\begin{array}{l}10 \text { years } \\
1999-2008\end{array}$ \\
\cline { 2 - 5 } & $\begin{array}{l}\text { Tuchola Forests (Wierzchlas Reserve sites) } \\
\text { Traps: W1, W2, W3 }\end{array}$ & $800-1,400 \mathrm{~m}$ & 229 & $\begin{array}{l}11 \text { years } \\
1998-2008\end{array}$ \\
\cline { 2 - 5 } & $\begin{array}{l}\text { Brodnica Lakeland } \\
\text { Traps: B1, B2, B3 }\end{array}$ & $400-1,700 \mathrm{~m}$ & 165 & $\begin{array}{l}11 \text { years } \\
1998-2008\end{array}$ \\
\hline
\end{tabular}

Dispersed $F$. sylvatica trees within regions dominated by pine forests and agricultural land

\begin{tabular}{|c|c|c|c|c|}
\hline \multirow[t]{3}{*}{ N Poland } & $\begin{array}{l}\text { Tuchola Forests (Laska sites) } \\
\text { Traps: LL, LS, LP }\end{array}$ & $250-300 \mathrm{~m}$ & 39 & $\begin{array}{l}10 \text { years } \\
1999-2008\end{array}$ \\
\hline & $\begin{array}{l}\text { Kashubian Lakeland (Chośnickie Lakes sites) } \\
\text { Traps: JC1, JC2, JC3 }\end{array}$ & $200-500 \mathrm{~m}$ & 104 & $\begin{array}{l}5 \text { years } \\
2004-2008\end{array}$ \\
\hline & $\begin{array}{l}\text { Toruń basin (Las Piwnicki Reserve sites) } \\
\text { Traps: LPL, LPS }\end{array}$ & $200-500 \mathrm{~m}$ & 137 & $\begin{array}{l}10 \text { years } \\
1998-2007\end{array}$ \\
\hline \multicolumn{5}{|c|}{$F$. sylvatica as admixture in lower elevation forest belt in the mountains } \\
\hline \multirow[t]{2}{*}{ Czech Republic } & $\begin{array}{l}\text { Šumava Mts } \\
\text { Traps: SA1-SA18 }\end{array}$ & $30-2,500 \mathrm{~m}$ & 151 & $\begin{array}{l}11 \text { years } \\
1997-2007\end{array}$ \\
\hline & $\begin{array}{l}\text { Krkonoše Mts } \\
\text { Traps: KR1-KR19 }\end{array}$ & $38-2,255 \mathrm{~m}$ & 133 & $\begin{array}{l}10 \text { years } \\
1998-2007\end{array}$ \\
\hline \multirow[t]{4}{*}{ Swiss Alps } & $\begin{array}{l}\text { Aletsch region } \\
\text { Traps: } \mathrm{A} 0, \mathrm{~A} 1, \mathrm{~A} 2, \mathrm{~A} 3, \mathrm{~A} 4, \mathrm{~A} 5\end{array}$ & $2,200-2,500 \mathrm{~m}$ & 79 & $\begin{array}{l}16 \text { years } \\
1992-2007\end{array}$ \\
\hline & $\begin{array}{l}\text { Grindelwald } \\
\text { Traps: G0 (only } 1996 \text { year data), G06, G07, } \\
\quad \text { G08, G10, G12, G13, G14, G15 }\end{array}$ & $1,500-3,500 \mathrm{~m}$ & 164 & $\begin{array}{l}12 \text { years } \\
1996-2007\end{array}$ \\
\hline & $\begin{array}{l}\text { Simplon } \\
\text { Traps: S1, S2, S3, S4, S5 }\end{array}$ & $3,000-4,000 \mathrm{~m}$ & 143 & $\begin{array}{l}16 \text { years } \\
1992-2007\end{array}$ \\
\hline & $\begin{array}{l}\text { Zermatt } \\
\text { Traps: Z1, Z2, Z3, Z4, Z5 }\end{array}$ & $15,000 \mathrm{~m}$ & 23 & $\begin{array}{l}15 \text { years } \\
1992-2007\end{array}$ \\
\hline
\end{tabular}



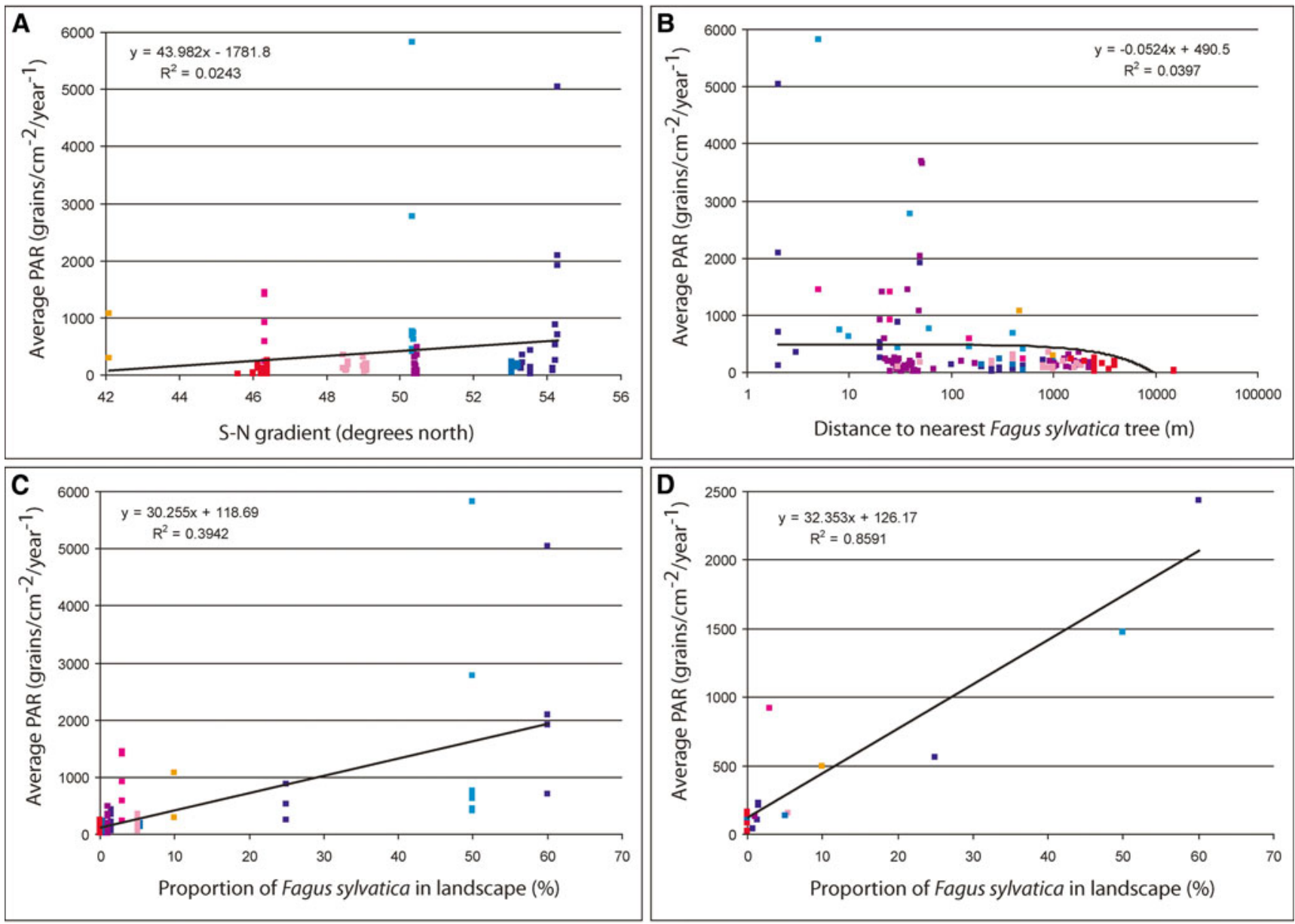

Fig. 4 Scatter plots comparing Fagus PAR averaged by trap (a-c) and averaged by region (d) to: the latitudinal gradient of trap locations (a); the distance to the nearest $F$. sylvatica tree (b); the proportion of $F$. sylvatica trees in the landscape (c); and the comparison of regional

traps at least $500 \mathrm{~m}$ above the Fagus forest. Also worth noticing are the distinct differences between northern Polish sub-regions with intermixed Fagus forest versus the occurrence of scattered trees. The latter situation with a sparse occurrence of Fagus is characterized by similar PAR values as those from the traps placed in mountains above and away from the nearest tree. However, it is reassuring to observe that the lowest average PAR was found in traps from the Zermatt sub-region in Switzerland, where the nearest Fagus tree is about $15 \mathrm{~km}$ away.

\section{Discussion}

High and low pollen-production years of Fagus

Our dataset clearly shows a high variability in the year-toyear pollen deposition of Fagus. We can show that individual trees have a high influence on the PAR in the pollen trap if they are standing close to it. Therefore the year-to-

PAR to the proportion of $F$. sylvatica trees in the landscape (d). The black lines represent the linear trend lines fitted to the data; for colour code, see Fig. 1

year difference in pollen deposition is influenced by the variability in flowering of individual trees. Thus, differences in flowering peaks in pollen traps from the same region indicate that not all trees within the same region have parallel variations in the amount of pollen production. The Polish data especially, but also the data from the high mountains (Swiss Alps and Rila Mts in Bulgaria) indicate that years with extremely high pollen production occur less frequently than years with low pollen production. The averaged annual pollen signal from a region clearly shows a parallel pattern to that of nearby regions (Table 1).

Years with generally high and low pollen production are often matched by high and low seed production. Hilton and Packham (2003) studied Fagus masting over two centuries (1800-2001) in northern Europe and found that years with very good mast occurred in Germany and Denmark only three times, the last in 1918. Thus, our data series may only be compared to moderate mast years, at least up to 2001, which are found to occur in one or two regions at the same time. Hilton and Packham (2003) presumed that mast 
follows a biennial cycle that would be influenced by climate, whereas Tonkov et al. (2001) observed a 5-year recurrence and Dzwonko (1990, after Garbaye et al. 1976) a 4- to 8-year recurrence of abundant flowering and seed production. According to Dzwonko, abundant seed production occurs more regularly in more continental climates, and Tomanek (1994) observes that mast occurs more frequently in lowland areas than in mountains. We did not however find any regular pattern either in the mast years reported for different regions or in the years of high pollen-production in any study region. In Switzerland, for example, masting during the period of pollen trapping occurred at irregular intervals, in 1992, 1995, 1999, 2001, 2003 and 2006. We found in our data that years of good mast are mostly also years of high pollen production. The year 2006 had peak pollen production in all study areas, which together with our incomplete regional information on mast fruiting suggests that it was also a mast year over large part of Europe. Masting depletes the resources of the tree, so that no mast occurs in the following year. Thus, after a mast year the tree should reduce the amount of pollen production in the next year (Isagi et al. 1997; Dahl and Strandhede 1996). This agrees with most of our data, but there are exceptions; the good mast in Switzerland in 2003 was followed by good flowering in 2004 . However, a good flowering year may not necessarily result in a good mast year as unfavourable weather conditions reducing seed production may still occur after flowering. This could explain some of the discrepancies observed between flowering and seed production. For example the high pollen deposition in the Rila Mts in 2001 and in Roztocze in 2003 was not matched by high seed production.

Extremely high years and low years of Fagus pollen deposition were recorded in most traps irrespective of their situation (small forest opening, open area, or forest edge). This evidences the role of climate for pollen production and release. Chałupka (1990 and reference therein), for example, described how higher-than-average June and July air temperature stimulated abundant flowering and seed production of beech in the following year, and he stressed the positive impact of July drought on seed production in the following year. Pidek and Kaszewski (2005) could confirm this for the Roztocze region in Poland, and also van der Knaap et al. (this volume) found for Roztocze a negative correlation of precipitation from July to November with Fagus PAR in the following year. Also, Matthews (1955) showed a significant correlation between the magnitude of a mast and July air temperature and sunshine in the preceding summer, and he stressed the damaging effect of spring frosts on the flowers of beech. Differences between regions in the occurrence of high and low Fagus pollen production years are probably related to different weather conditions in the pollen-source areas.
A comparison of Fagus PAR between $F$. orientalis in the Strandzha Mts and F. sylvatica in the Rila Mts (Bulgaria) reveals that high and low pollen-production years do not coincide in the two species, except for 2005 that can be considered a high pollen year for both. High pollen deposition in the Rila Mts in 1999 and in 2007 was supported by a very good mast.

Pollen thresholds for Fagus presence/absence in the vegetation

The good linear relationship between the abundance of Fagus trees and the sub-regional averages of Fagus PAR shows impressively that the presumed linear relationship between tree abundance and PAR holds true (Davis et al. 1973; Seppä et al. 2009). The average pollen values presented in Table 2 may be compared with fossil data to serve as a modern analogue for the abundance of Fagus trees. Situations where the pollen traps were placed far away from the nearest tree give an estimate of the amount of average regional Fagus pollen, which lies in the order of 10-40 grains $\mathrm{cm}^{-2}$ year $^{-1}$ (Zermatt). These values almost cannot be distinguished from PAR observed in a region with low Fagus abundance such as Laska site in Tuchola Forests where the 10-year average over three pollen traps is as low as 40 grains $\mathrm{cm}^{-2}$ year $^{-1}$.

Presence of beech forest within $2 \mathrm{~km}$ of the pollen traps results in a Fagus PAR of ca. $700 \mathrm{~cm}^{-2}$ year ${ }^{-1}$ in the Rila Mts (Bulgaria) and an average of ca. $1,400 \mathrm{~cm}^{-2}$ year ${ }^{-1}$ in Roztocze (SE Poland). The maximum in Roztocze is ca. $2,400 \mathrm{~cm}^{-2}$ year $^{-1}$, when beech trees grow very close to the trap in a region where Fagus forms tree stands. Results similar to Roztocze were obtained for the Gdańsk region (northern Poland) and the Strandzha Mts (Bulgaria; F. orientalis) where the records are shorter (less years).

In northern Poland, small Fagus-dominated patches in the forest resulted in an average Fagus PAR of ca. 170$220 \mathrm{~cm}^{-2}$ year $^{-1}$ (Tuchola Forests, Brodnica Lakeland), and of ca. $550 \mathrm{~cm}^{-2}$ year $^{-1}$ when such a patch grows close to the pollen traps (PL SB sites in Kashubian Lakeland). Average Fagus PAR reached only $40-100 \mathrm{~cm}^{-2}$ year ${ }^{-1}$ when Fagus trees were sparse in pine-dominated forest (Tuchola Forests, PL JC sites in Kashubian Lakeland). An interesting case is the Torun Basin (Las Piwnicki Reserve) where a single Fagus tree in the forest at $200 \mathrm{~m}$ distance resulted in an average Fagus PAR of $137 \mathrm{~cm}^{-2}$ year ${ }^{-1}$, whereas in Roztocze a single beech tree growing $10 \mathrm{~m}$ from trap PL G1 in a small forest opening resulted in an average Fagus PAR of $624 \mathrm{~cm}^{-2}$ year ${ }^{-1}$, which illustrates the impact that a single tree can have.

Average Fagus PAR is similar in all traps in the Krkonoše and Šumava Mts (Czech Republic) in spite of different proportions of beech trees in the nearest forests at 
lower elevations. This indicates that pollen transport by mountain winds is effective over large distances. The same is probably the case in the Swiss Alps. In both countries, average Fagus PAR is ca. $150 \mathrm{~cm}^{-2}$ year $^{-1}$ when the nearest beech trees grow at ca. $2 \mathrm{~km}$ from the traps. In the Swiss Jura Mts, on the other hand, beech trees grow closer to the traps and average Fagus PAR is accordingly higher $\left(922 \mathrm{~cm}^{-2}\right.$ year $\left.^{-1}\right)$. The comparison has, however, its limitations, because both the short time series in the Swiss Jura Mts and the long time series in the Swiss Alps include the same 2 years with extremely high PAR.

A comparison between average $F$. orientalis and $F$. sylvatica PARs in Bulgaria is hampered by differences in trap locations and length of time series. The two traps that have the most similar positions in relation to Fagus trees yielded the rather similar average Fagus PARs of $1,606 \mathrm{~cm}^{-2}$ year $^{-1}$ for $F$. orientalis and $1,083 \mathrm{~cm}^{-2}$ year $^{-1}$ for $F$. sylvatica, which suggests that the two beech species produce approximately similar amounts of pollen, but this needs confirmation.

This study revealed that more than one pollen trap should be employed for a number of years if pollen traps are used to find relationships between PAR and tree abundance or biomass. Essential to our study were also the use of a variety of study regions, including both lowlands and mountains, and good records of the vegetation structure and abundance of beech trees in the estimated pollensource area of the tree, which we needed to establish pollen-threshold values of Fagus presence/absence in the vegetation. The large size of our dataset helps to reduce the noise inherent in results from Tauber traps and in the study of a single taxon in a range of habitats. Our results are useful for the interpretation of fossil pollen diagrams in terms of occurrence and abundance of beech trees in the vegetation. This is especially important when studying the Holocene expansion of Fagus in Europe in different climatic regions. In addition, our results shed some light on the reproductive strategies of the tree, by starting to show the relationships between fruit masting and mass pollen production.

\section{Conclusions}

Across a N-S European transect, the variability in annual PAR of Fagus is larger between years in the same trap than between traps of the same year within the same region. Years with extremely high pollen production occur less frequently than years with low pollen production and are often matched by high and low seed production. There is good geographic coincidence in 2005, a low flowering year in all regions except Bulgaria, and in 2006, a high flowering year in many regions. Further examples of clear synchronicities can be seen between sub-regions of the same country such as the different mountain regions of the Swiss Alps or of the Czech Republic.

High and low years of Fagus pollen deposition were recorded in most traps irrespective of their situation (small forest opening, open area, or forest edge). This evidences the role of climate in pollen production and release.

The average deposition of Fagus pollen in each site can be explained by the regional abundance of the tree modulated by local site-specific factors. The proportion of Fagus in the regional vegetation is explaining about $85 \%$ of the variance in sub-regional averages of PAR.

A Fagus PAR of ca. 10-40 grains cm $\mathrm{cm}^{-2}$ year $^{-1}$ was recorded in situations where the pollen traps were placed far away from the nearest beech tree. Presence of beech forest within $2 \mathrm{~km}$ of the pollen traps results in a Fagus PAR of ca. $700 \mathrm{~cm}^{-2}$ year $^{-1}$ (Rila Mts, Bulgaria) and ca. $1,400 \mathrm{~cm}^{-2}$ year $^{-1}$ (Roztocze, Poland) in a region where Fagus forms tree stands. In the Krkonoše and Šumava Mts (Czech Republic), in spite of different proportions of beech trees in the nearest forests at lower elevations, similar average Fagus PAR in all traps stresses the effectiveness of pollen transport over large distances in the mountains. The same is probably the case in the Swiss Alps. The two traps that have the most similar positions in relation to trees of different Fagus species yielded the rather similar average Fagus PAR of $1,606 \mathrm{~cm}^{-2}$ year $^{-1}$ for $F$. orientalis and $1,083 \mathrm{~cm}^{-2}$ year $^{-1}$ for $F$. sylvatica. This suggests that the two beech species produce approximately similar amounts of pollen, but this needs confirmation.

Acknowledgements We would like to express our gratitude to the founder of PMP Sheila Hicks, for her constant care, help, friendship, support and cooperation. Donatella Magri and an anonymous reviewer made valuable comments. Jan Rodzik (Head of the Roztocze Research station) has been supporting PMP since 1998. The Administrators of the Roztocze National Park, Krkonoše National Park and Šmava National Park and Reserve granted permission to enter the highly protected zones of the National Parks. Jan Wild, Zdenka Konopová (Institute of Botany AS CR), and Josef Harčarik (Administration of Krkonoše N.P.) carried out GIS mapping of Fagus. Zdenka Procházková (Forestry and Game Management Research Institute Strnady, Jíloviště, Czech Republic), Daniel Černý (Administration of Šumava N.P. and Reserve), Anton Burkart (WSL Switzerland), and K. Galabov, B. Taseva and G. Popov (Bulgaria) provided information on Fagus masting years. Part of this work was financially supported by the Polish Ministry of Science and Higher Education (project N304 092 32/3590; 2007-2010). The Pollen Monitoring Programme in the Czech Republic was funded by the Academy of Sciences (AV0Z60050516) and the Grant Agency of the Academy of Sciences of the Czech Republic (IAAX00130801 and IAAX00050801). This research is part of the Pollen Monitoring Programme PMP (INQUA working group; http://pmp.oulu.fi/) and contributes to the European Union project Millennium-European climate of the last millennium (SUSTDEV-2004-3.1.4.1). 


\section{References}

Birks HJB (1996) Contribution of Quaternary palaeoecology to nature conservation. J Veg Sci 7:89-98

Botkin DS, Saxe H, Araujo M, Bradshaw RHW, Chesson P, Dawson T, Etterson J, Faith D, Guisan A, Ferrier S, Kareiva P, Margules C, New M, Sobel M, Stockwell D (2007) Some suggestions for forecasting effects of global warming on biodiversity. Bioscience 57:227-236

Bradshaw RHW (2008) Detecting human impact in the pollen record using data-model comparison. Veget Hist Archaeobot 17:597603

Brewer S, Cheddadi R, de Beaulieu J-L, Reille M (2002) The spread of deciduous Quercus throughout Europe since the last glacial period. For Ecol Manag 156:27-48

Broström A, Sugita S, Gaillard M-J (2004) Pollen productivity estimates for the reconstruction of past vegetation cover in the cultural landscape of southern Sweden. Holocene 14:371-384

Broström A, Nielsen A-B, Gaillard M-J, Hjelle K, Mazier F, Binny H, Bunting J, Fyfe R, Meltsov V, Poska A, Räsänen S, Sopboer W, von Stedingk H, Suutari H, Sugita S (2008) Pollen productivity estimates of key European plant taxa for quantitative reconstruction of past vegetation: a review. Veget Hist Archaeobot 17:461-478

Calcote R (1995) Pollen source area and pollen productivity: evidence from forest hollows. J Ecol 83:591-602

Chałupka W (1990) Wybrane zagadnienia rozwojowe i wzrostowe [Selected problems of growth and development]. Buk [Beech] (Fagus sylvatica L.). Nasze drzewa leśne 10 [Our forest trees 10]. PWN, Warszawa-Poznań, pp 123-141 (in Polish with English summary)

Cheddadi R, Vendramin GG, Litt T, Francois L, Kageyama M, Lorentz S, Laurent J-M, de Beaulieu J-L, Sadori L, Jost A, Lunt D (2006) Imprints of glacial refugia in the modern genetic diversity of Pinus sylvestris. Glob Ecol Biogeogr 15:271-282

Dahl A, Strandhede S-O (1996) Predicting the intensity of the birch pollen season. Aerobiologia 12:97-106

Davis MB, Brubaker LB, Webb T III (1973) Calibration of absolute pollen influx. In: Birks HJB, West RG (eds) Quaternary plant ecology. Blackwell, Oxford, pp 9-25

Dzwonko Z (1990) Ekologia [Ecology] [in:] Białobok S (ed) Buk [Beech] (Fagus sylvatica L.). Nasze drzewa leśne 10 [Our forest trees 10]. PWN, Warszawa-Poznań, pp 237-328 (in Polish with English summary)

EUFORGEN (2009) Distribution map of oriental beech (Fagus orientalis). www.euforgen.org

Gaillard M-J, Sugita S, Bunting JM, Middleton R, Broström A, Caseldine C, Giesecke T, Hellman SEV, Hicks S, Hjelle K, Langdon C, Nielsen A-B, Poska A, von Stedingk H, Veski S, POLLANDCAL Members (2008) The use of modelling and simulation approach in reconstructing past landscapes from fossil pollen data: a review and results from the POLLANDCAL network. Veget Hist Archaeobot 17:419-443

Garbaye J, Le Tacon F, Timbal J (1976) Le hêtre en Romanie. Rev For Fran 28:243-260

Giesecke T, Hickler T, Kunkel T, Sykes MT, Bradshaw R (2007) Towards an understanding of the Holocene distribution of Fagus sylvatica L. J Biogeogr 34:118-131

Giesecke T, Fontana SL, van der Knaap WO, Pardoe H, Pidek IA (2010) From early pollen trapping experiments to the Pollen Monitoring Programme. Veget Hist Archaeobot (this volume)

Hicks S (1996) The feasibility of using pollen deposition data as climatic indices. Paläoklimaforschung 20:173-187

Hicks S (2005) When no pollen does not mean no trees. Veget Hist Archaeobot 15:253-261
Hicks S, Hyvärinen V-P (1986) Sampling modern pollen deposition by means of 'Tauber traps': some considerations. Pollen Spores 28:219-242

Hicks S, Ammann B, Latałowa M, Pardoe H, Tinsley H (1996) European Pollen Monitoring Programme: project description and guidelines. Oulu University Press, Oulu

Hilton GM, Packham JR (2003) Variation in the masting of common beech (Fagus sylvatica L.) in northern Europe over two centuries(1800-2001). Forestry 76:319-328

Hjelle KL (1998) Herb pollen representation in surface moss samples from mown meadows and pastures in western Norway. Veget Hist Archaeobot 7:79-96

Huusko A, Hicks S (2009) Conifer pollen abundance provides a proxy for summer temperature: evidence from the latitudinal forest limit in Finland. J Quat Sci 24:522-528

Isagi H, Sugimura K, Sumida A, Ito H (1997) How does masting happen and synchronize? J Theor Biol 187:231-239

Jalas J, Suominen J (eds) (1972-1999) Atlas Florae Europaeae: distribution of vascular plants in Europe. The Committee for mapping the flora of Europe and Societas Botanica Fennica, Vanamo, Helsinki

Latałowa M, van der Knaap WO (2006) Late Quaternary expansion of Norway spruce Picea abies (L.) Karst. in Europe according to pollen data. Quat Sci Rev 25:2780-2805

Latałowa M, Ralska-Jasiewiczowa M, Miotk-Szpiganowicz G, Zachowicz J, Nalepka D (2004) Fagus sylvatica L.-Beech. In: Ralska-Jasiewiczowa M, Latałowa M, Wasylikowa $\mathrm{K}$, Tobolski K, Madeyska E, Wright HE Jr, Turner C (eds) Late Glacial and Holocene history of vegetation in Poland based on isopollen maps. W. Szafer Institute of Botany, Polish Academy of Sciences, Kraków, pp 95-104

Liepelt S, Cheddadi R, de Beaulieu J-L, Fady B, Gömöry D, Hussendörfer E, Konnert M, Litt T, Longauer R, Terhürne-Berson R, Ziegenhagen B (2009) Postglacial range expansion and its genetic imprints in Abies alba (Mill.) — a synthesis from palaeobotanic and genetic data. Rev Palaeobot Palynol 153:139-149

Magri D, Vendramin GG, Comps B, Dupanloup I, Geburek T, Gömöry D, Latałowa M, Litt T, Paule L, Roure JM, Tantau I, van der Knaap WO, Petit RJ, de Beaulieu J-L (2006) A new scenario for the Quaternary history of European beech populations: palaeobotanical evidence and genetic consequences. New Phytol 171:199-221

Matthews JD (1955) The influence of weather on the frequency of beech mast years in England. Forestry 28:107-116

Pidek IA (2004) Preliminary results of pollen trapping in the region of the Roztocze National Park (SE Poland). Annales UMCS Sect B 49:143-159

Pidek IA, Kaszewski BM (2005) Zmienność koncentracji pyłku buka zwyczajnego (Fagus sylvatica L.) w lasach Roztocza na tle czynników meteorologicznych [Variation of beech (Fagus sylvatica L.) pollen concentration in the Roztocze forests against the background of meteorological factors]. Annales UMCS Sect B 60:147-163 (in Polish with English summary)

Poska A, Pidek IA (2010) Pollen dispersal and deposition characteristics of Abies alba, Fagus sylvatica and Pinus sylvestris, Roztocze region (SE Poland). Veget Hist Archaeobot 19:91-101

Seppä H, Hicks S (2006) Integration of modern and past pollen accumulation rate (PAR) records across the arctic tree-line: a method for more precise vegetation reconstructions. Quat Sci Rev 25:1501-1516

Seppä H, Alenius T, Muukkonen P, Giesecke T, Miller PA, Ojala AEK (2009) Calibrated pollen accumulation rates as a basis for quantitative tree biomass reconstructions. Holocene 19:209-220

Sjögren P, van der Knaap WO, Huusko A, van Leeuwen JFN (2008) Pollen productivity, dispersal, and correction factors for major 
tree taxa in the Swiss Alps based on pollen-trap results. Rev Palaeobot Palynol 152:200-210

Stockmarr J (1971) Tablets with spores used in absolute pollen analysis. Pollen Spores 13:615-621

Sugita S (1994) Pollen representation of vegetation in Quaternary sediments theory and methods in patchy vegetation. J Ecol 82:879-898

Tauber H (1974) A statistic non-overload pollen collector. New Phytol 73:359-369

Terhürne-Berson R, Litt T, Cheddadi R (2004) The spread of Abies throughout Europe since the last glacial period: combined macrofossil and pollen data. Veget Hist Archaeobot 13:257-268

Tinner W, Lotter AF (2006) Holocene expansion of Fagus sylvatica and Abies alba in Central Europe: where are we after eight decades of debate? Quat Sci Rev 25:526-549

Tollefsrud MM, Kissling R, Gugerli F, Johnsen O, Skroppa T, Cheddadi R, van der Knaap WO, Latałowa M, Terhürne-Berson R, Litt T, Geburek T, Brochmann C, Sperisen C (2008) Genetic consequences of glacial survival and postglacial colonization in Norway spruce: combined analysis of mitochondrial DNA and fossil pollen. Mol Ecol 17:4134-4150

Tomanek J (1994) Botanika leśna [Forest botany] Państwowe Wydawnictwa Rolnicze i Leśne, 5 edn. Warszawa (in Polish)
Tonkov S, Hicks S, Bozilova E, Atanassova J (2001) Pollen monitoring in the central Rila Mountains, Southwestern Bulgaria: comparisons between pollen traps and surface samples for the period 1993-1999. Rev Palaeobot Palynol 117:167-182

van der Knaap WO, van Leeuwen JFN, Ammann B (2001) Seven years of annual pollen influx at the forest limit in the Swiss Alps studied by pollen traps: relations to vegetation and climate. Rev Palaeobot Palynol 117:31-52

van der Knaap WO, van Leeuwen JFN, Svitavská-Svobodová H, Pidek IA, Kvavadze E, Chichinadze M, Giesecke T, Kaszewski BM, Oberli F, Kalnina L, Pardoe HS, Tinner W, Ammann B (2010) Annual pollen traps reveal the complexity of climatic control on pollen productivity in Europe and the Caucasus. Veget Hist Archaeobot (this volume). doi:10.1007/s00334010-0250-6

Załęski A, Kantorowicz W et al (1999-2008) Komunikaty o przewidywanym urodzaju nasion najważniejszych gatunków drzew leśnych w Polsce [Forecast of seed production of the most important forest forming trees in Poland], 52 (1999), 53 (2000), 54 (2001), 55 (2002), 56 (2003), 57 (2004), 58 (2005), 59 (2006), 60 (2007), 61 (2008). Instytut Badawczy Leśnictwa, Warszawa (in Polish) 